\title{
目標耐震性能に必要な降伏強度と 塑性率のスペクトル
}

\author{
家村浩和 1 ・三上 卓2 \\ 1フェロー 工博 京都大学教授 工学研究科土木システム工学専攻 ( T 606-8501 京都市左京区吉田本町) \\ 2 正会員 博士(工学) 京都大学リサーチ・アソシエイト 工学研究科土木システム工学専攻 (同上)
}

\begin{abstract}
近年, 各種構造物の設計基準等において採用され始めている性能照査型設計では, 構造物に対する要求 性能と，それを具体的に実現するための目標性能指標が明確に規定されなければならない．本論文は，従 来から研究されている損傷度指標をその目標性能指標として用いることとし, 弹塑性地震応答解析により, その目標性能指標を満足するために必要な降伏強度と塑性率のスペクトルの提案を行なったものである.
\end{abstract}

Key Words : performance based design, damage index, demand spectra, yielding strength, ductility factor, inelastic seismic design

\section{1. 序論}

近年，土木・建築構造物の設計では，性能照査型 設計が新たに採用されようとしている。これまでの 耐震設計は, 設計地震力および設計手順の詳細を規 定した仕様設計が中心であり，基準に従うことのみ が要求されたのである. 設計された構造物が設計荷 重以上のどの程度の地震力に耐え得る性能を有する か, などについては全く問題とされなかった ${ }^{1)}$.

SEAOC (Structural Engineers Association of California) のVision $2000^{2)}$ では, 地震荷重と構造物の重要度ご とに，まず，目標性能を設定し，これを満足するよ うに設計を進める, 性能照查型設計法の枠組みが提 案された。 日本でも, 兵庫県南部地震の被災経験か ら，性能照査型設計が様々な構造物に対して議論さ れており ${ }^{3), 4)}$, 本格的に調查研究が進められている. 現時点では, 性能・照査という言葉が先行しがちで, どのような設計体系になるのかなど，その具体的な イメージが掴めていない. しかし, 公共事業におけ るコスト縮减, 新技術の開発促進を積極的に推進し, 設計の自由度を高めた耐震設計基準とするために, 構造物に要求される性能水準の明確化および構造物 の保有する性能の評価手法の開発ならびにそれらの 具体的設計法への展開が必要となってきている.

地震による構造物の損傷度については, 以前より 様々な研究がなされてきた。 中でも，Parkと Ang ${ }^{5)}$, Krawinkler と Zorei ${ }^{6)}$ やKumar とUsami $^{7)}$ によって, 地
震による構造物の損傷度を定量的に表すことを目的 とした様々な指標が提案されてきた. 鈴木ら ${ }^{8)}$ は, Park とAngの損傷度指標を用いて, 地震時のRC橋脚 の被害を予測する簡便な地震被害算定指標を構築し, 実際に生じた被害との検証等を行い, さらに, 履歴 吸収エネルギーのみを用いた損傷指標の提案とそれ を用いた地震時損傷度評価を行っている99.

本論文では, 地震時の構造物の損傷度を数值的に 表現する損傷度指標を用いた『性能評価を基盤にし た設計体系の流れ』を提案する. 最初に, その中で 最も重要な損傷度指標に対して, 入力地震動や構造 パラメータがどのような影響を及ぼすかを検討する。 さらに, 性能照查型設計に用いる目標性能を損傷度 指標を用いて表現し, 構造物の目標性能に対応する 損傷度指標の目標值を設定する. そして, その目標 值を満たす降伏強度や最大変位 (塑性率) といった構 造特性を 1 自由度系弾塑性応答解析により算定する. 目標性能に対応する損傷度指標の目標值に応じた必 要降伏強度・応答塑性率のスペクトルの作成を行い, 性能照查型設計法の目標性能指標としての損傷度指 標の有効性を検討する.

\section{2. 損傷度指標を用いた性能照査型設計法}

\section{（1）性能評価を基盤にした設計体系の流れ}

著者らは, 図-1のような, 性能評価を基盤にした 


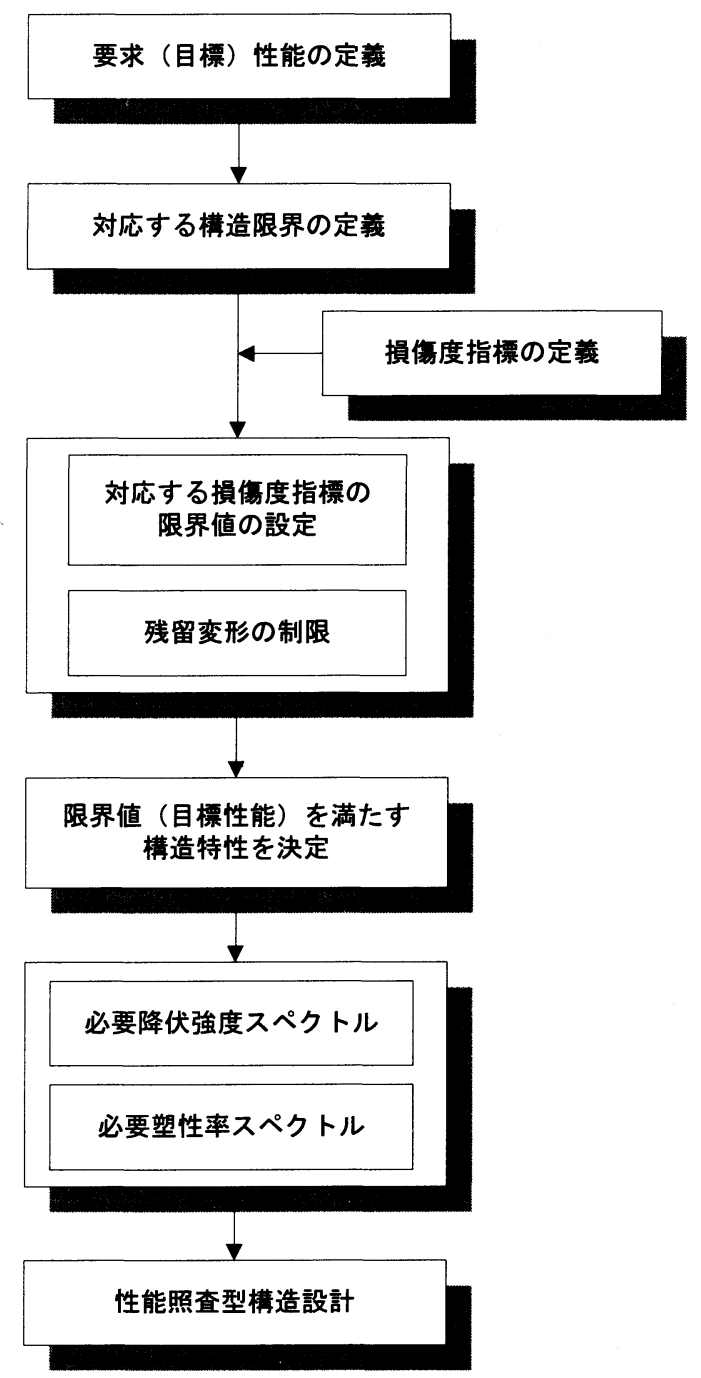

図-1 性能評価を基盤にした設計体系の流れ

設計体系の流れを提案した ${ }^{10)}$. 始めに，地震による 構造物の要求性能を定義し, それに対応する構造限 界を定義する. これらの定義は, 道路橋示方書 ${ }^{11)}$ 鉄道構造物等設計標準 ${ }^{12)}$ で, 既に定義されている. 一方で, 地震による構造物全体の損傷程度を数値的 に表現している損傷度指標を定義し, 先に定義した 構造限界に対応する損傷度指標の限界值を設定する. そして, 1 自由度系の弾塑性応答解析により, 限界 值 (目標性能)を満たす構造特性を決定する.ここで の構造特性とは, 必要降伏強度および必要塑性率で ある，得られた構造特性を用いることにより，損傷 度指標を用いた性能照査型設計を具体的に行うこと ができる.
表-1 損傷状態と損傷度指標の関係

\begin{tabular}{|c|c|c|}
\hline 損䂓状態 & 損侮度指標の值 & 構造物の外钼 \\
\hline 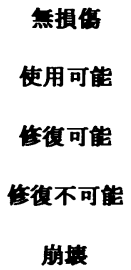 & $\begin{array}{c}0.08 \\
0.18 \\
0.36 \\
0.60\end{array}$ & 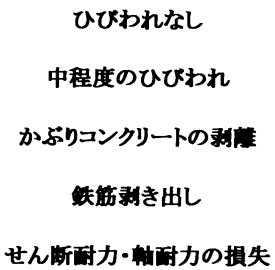 \\
\hline
\end{tabular}

\section{（2）損偒度指標の定義}

図-1に示した設計体系の流れでキーポイントとな るのが, 損賃度指標である. 本論文では, 既往の研 究 $^{10)}$ を参考に, 式(1)の損傷度指標DI ${ }^{13)}$ を用いた。 この損傷度指標は, Park と Ang ${ }^{5)}$ にり開発され， Kunnath ${ }^{14)}$ により構造物が弾性挙動をしてしてい るときにはDK 0 となるように，修正された指標で ある。

$$
D I=\frac{\mu_{d}-1}{\mu_{u}-1}+\frac{\beta \cdot \mu_{h}}{\mu_{u}}
$$

ここで, $\mu d, \mu u, \mu h$ はそれぞれ応答塑性率, 終局 変位勒性率, エネルギー勒性率であり, 式(2)～式 (4)で定義される. また, 式(1)の $\beta$ は部材の断面特 性等に依存した正の係数であり，広範な値を持ち， 定かではないが, ここでは, その平均值 $\beta=0.15$ と した.

$$
\begin{aligned}
\mu_{d} & =\delta_{\max } / \delta_{y} \\
\mu_{u} & =\delta_{u} / \delta_{y} \\
\mu_{h} & =E_{h} /\left(P_{y} \cdot \delta_{y}\right)
\end{aligned}
$$

ここで， $\delta_{\max } ， \delta y ， \delta_{u}$ は，それぞれ，最大変位， 降伏変位, 終局変位であり, EhおよびP P は, それぞ れ，履歴吸収エネルギーおよび降伏強度である(図一 3参照).

なお, 式(1)の損傷度指標DI の值と構造物の損傷 状態および構造物の被害の外観は Singhal と Kiremidjian $^{15)}$ PGhobarah ${ }^{13), 16)}$ によって，実在する 鉄筋コンクリート構造物の地震後の被害状況を測定 して，表-1のように提案されている．例えば，損傷 度指標の值 $D=0.36$ は, 損傷状態が修復可能と修復 不可能の境界にある状態, 寸なわち, 修復可能限界 を表す. 同様に, $D=0.6$ は, 修復不可能と崩壊の境 界であり， $D>0.6$ で崩壊となることを表す．この関

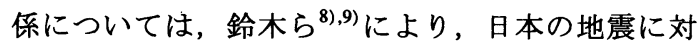
する適用性の確認が行われている. 

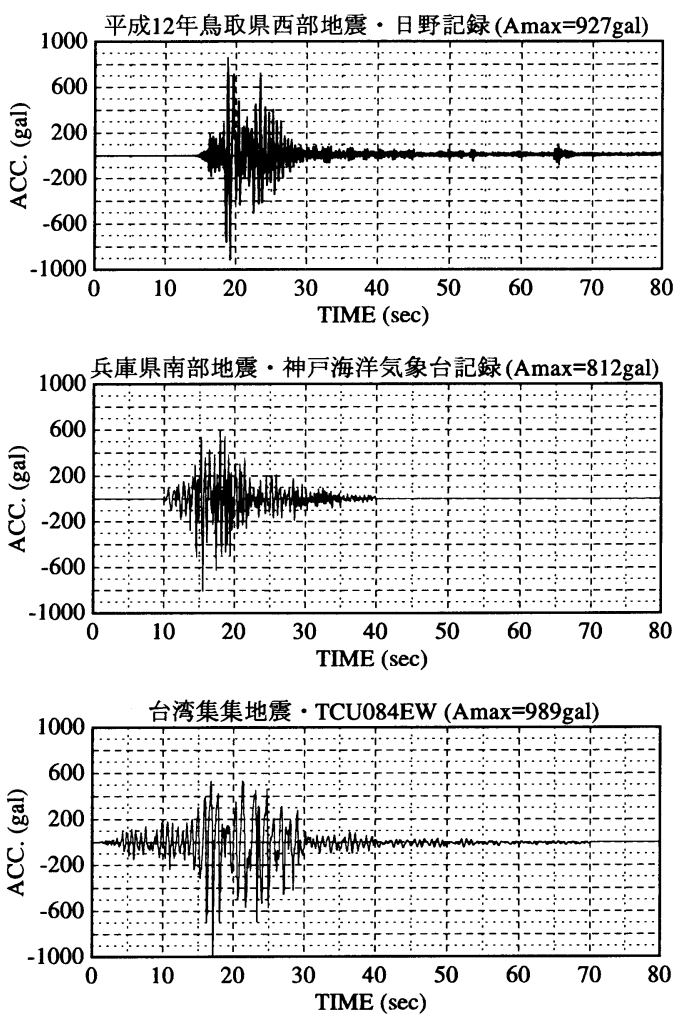

図-2 入力地震動波形 ${ }^{17), ~ 18) ~}$

\section{（3）損傷度指標と構造パラメータ}

\section{a) 解析方法}

性能照査型設計において 2 (2) で定義した損傷度 指標を用いるには，様々な入力地震動や構造パラ メータに対する依存性を検討しておく必要がある.

そこで，2（2）で定義した損傷度指標と構造パラ メータの関係を調べることにした．本論文では，入 力地震動と構造パラメータが損傷度指標に及ぼす影 響のみを検討するために，もっともシンプルで，道 路橋示方書 ${ }^{11)}$ で採用されている完全弾塑性型復元 力特性を有する 1 自由度系モデルに対する時刻歴応 答解析を行い，入力地震動および降伏強度の違いが 損傷度指標 $D I$ の値に及ぼす影響を検討した.

入力地震動には, 兵庫県南部地震・神戸海洋気象 台記録 NS 成分 $(A \max =812 \mathrm{gal})$, 台湾集集地震 TCU 084 記録 EW 成分 ${ }^{17)}(A \max =989 \mathrm{gal})$, 鳥取 県西部地震・日野記録 $\left.{ }^{18}\right)(A \max =927 \mathrm{gal})$ を用いた

（図-2）。構造パラメータは，降伏強度を $0.2 \mathrm{~g}$, $0.4 \mathrm{~g}, 0.6 \mathrm{~g}, 0.8 \mathrm{~g}, 1.0 \mathrm{~g}$ の 5 通り, 許容塑性率 $\mu_{a}=5$ の 1 通りとした。 その際, 減衰比 $h=0.05$ として解析 を行った.

また, 本論文では, 復元力履歴特性の 2 次剛性比 の影響を検討することにした．現行の道路橋示方書

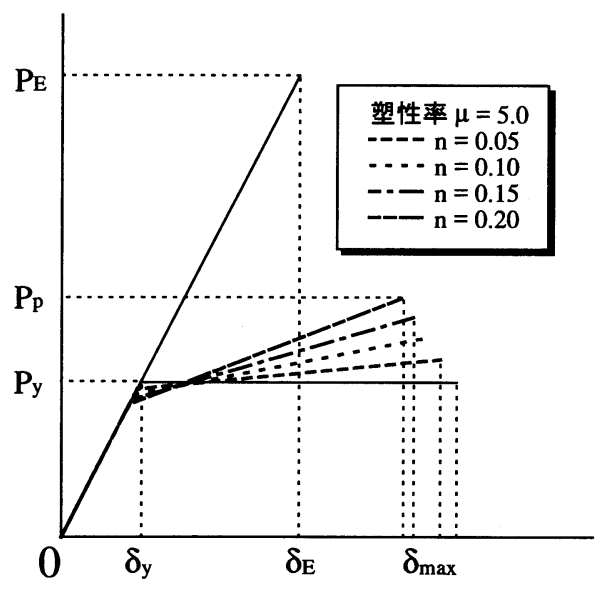

図-3２次剛性比と履歷特性の関係

$\mathrm{V}$ 耐震設計編 ${ }^{11)}$ では，L2地震動に対する保有耐力の 照查の過程において，鉄筋コンクリート橋脚の復元 力特性を降伏後の 2 次剛性比が0である完全弾塑性 型にモデル化している．しかし，近年，コンクリー 卜充填鋼製橋脚が開発されたように，今後，様々な 復元力特性を有する高耐震性鉄筋コンクリート橋脚 が開発される可能性がある ${ }^{19)}$ 。そこで，2 次剛性比 の影響を検討する際の履歴曲線を，エネルギー一定 則を用いて，次のように定義した。許容塑性率 $\mu$ を 一定として，エネルギー一定則を用いて， $P_{p} / P E$ と $P_{y} / P_{E}$ を, 2 次剛性比 $n$, 塑性率 $\mu\left(=\delta_{\max } / \delta_{y}\right)$ を用いて表すと, 式(5)と式(6)のようになる.

$$
\begin{aligned}
& \frac{P_{p}}{P_{E}}=\frac{1+n \cdot(n-1)}{\sqrt{n \cdot(n-1)^{2}+(2 \cdot \mu-1)}} \\
& \frac{P_{y}}{P_{E}}=\frac{1}{\sqrt{n \cdot(n-1)^{2}+(2 \cdot \mu-1)}}
\end{aligned}
$$

この関係を $n=0.05 \sim 0.20, \mu=5$ として図化すると, 図-3 となる. 図より，2 次剛性比 $n$ が大きくなる と, 最大耐力が降伏耐力より大きくなり，降伏耐力 が低减される.さらに, 残留変位も小さくなること も確認されいている ${ }^{19)}$. 例えば, 2 次剛性比 $n=$ 0.10 とすると, 降伏耐力 $P_{y}$ が $n=0.00$ の降伏耐力の $92 \%$ 程度になり, 最大変位も减少しており, 構造物 に塑性域の剛性を付加すれぼ, 従来の完全弾塑性型 の復元力特性を有する構造物に比べて, 降伏耐力お よび最大変位の低減といった耐震設計上有利な効果 が期待できる．さらに，残留変位が減少する結果， 地震後の修復もより容易となる．解析では，式 (6) 


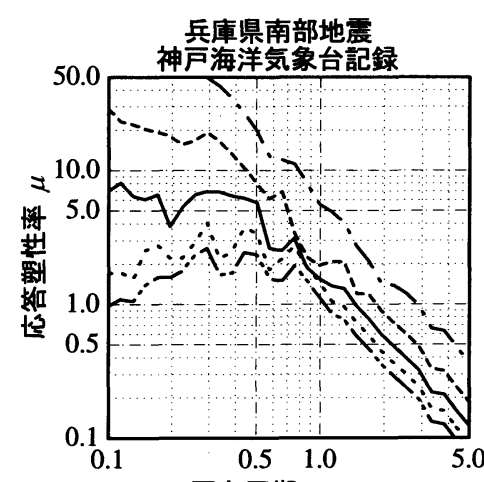

固有周期 $T(\mathrm{sec})$

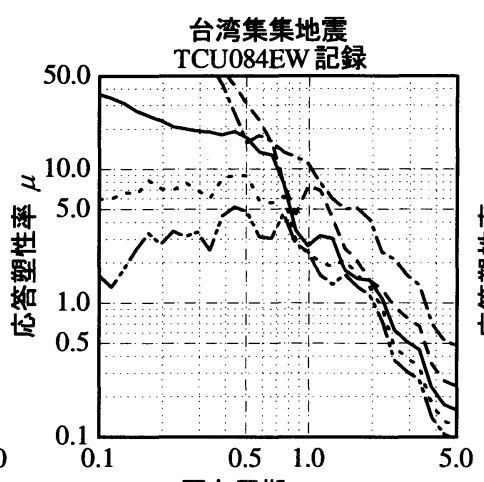

固有周期 $T(\mathrm{sec})$

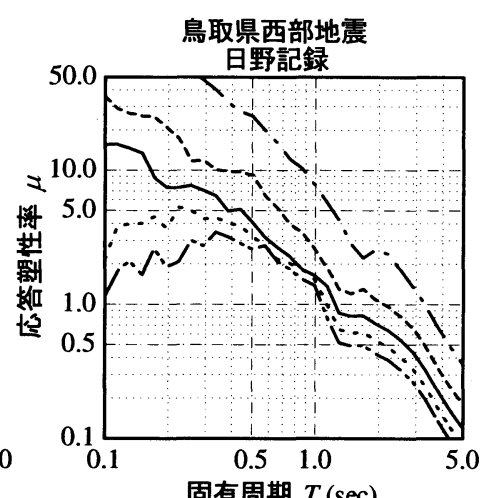

固有周期 $T(\mathrm{sec})$

$$
--P_{y}=0.2 \mathrm{~g}, \quad--P_{y}=0.4 \mathrm{~g},-P_{y}=0.6 \mathrm{~g}, \cdots P_{y}=0.8 \mathrm{~g}, \cdots-P_{y}=1.0 \mathrm{~g}
$$

図-4 入力地震動と降伏強度が応答塑性率に及ぼす影響
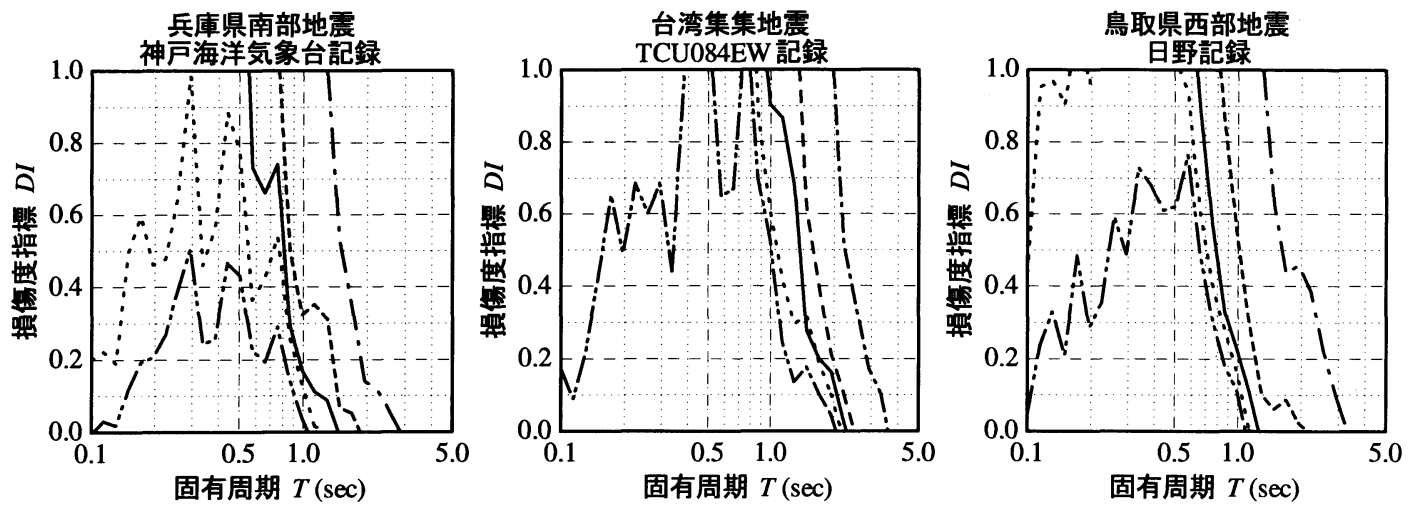

$$
-\cdot-P_{y}=0.2 \mathrm{~g},---P_{y}=0.4 \mathrm{~g},-P_{y}=0.6 \mathrm{~g}, \cdots P_{y}=0.8 \mathrm{~g}, \cdots-P_{y}=1.0 \mathrm{~g}
$$

図-5 入力地震動と降伏強度が損傷度指標に及ぼす影響（許容塑性率 $\mu a=5 ）$

より求まる $P y$ と $n$ の組み合わせを用いることとし た.

\section{b) 解析結果}

図-4は，降伏強度が応答塑性率に及ぼす影響を入 力地震動ごとに示した図である。同図より，兵庫県 南部地震 (神戸海洋気象台記録)，鳥取県西部地震 (日野記録), 台湾集集地震 (TCU084EW) の順に, 応 答塑性率が大きくなっており, 台湾集集地震の威力 が大きかったことがわかる，また，許容塑性率が

「橋脚の致命的な損傷に対しての安全性が確保され る塑性率」 ${ }^{11)}$ と考えると, RC橋脚で一般的な許容 塑性率 $\mu a=5$ を確保するには，弾性周期によりその 值は異なるが, 最大で兵庫県南部地震では $0.7 \mathrm{~g}$, 鳥 取県西部地震では $0.8 \mathrm{~g}$, 台湾集集地震では $0.9 \mathrm{~g}$ 程度 の降伏強度が必要であると考えられる.

図-5は，図-4のときの入力地震動および降伏強度 の違いが損傷度指標 $D I$ に及ぼす影響を示したもの
である．損傷度指標DI は，式(1)により算定される が, 式中の $\mu u$ は, 構造物の許容塑性率 $\mu_{a}=5$ と想定 し，式(7) ${ }^{11)}$ を用いて， $\mu_{u}=7$ とした.

$$
\mu_{a}=1+\frac{\delta_{u}-\delta_{y}}{\alpha \cdot \delta_{y}}=1+\frac{\mu_{u}-1}{\alpha}
$$

ここに， $\delta y ， \delta u$ はそれぞれ，降伏変位，終局変位， $\mu u$ は終局変位勒性率を表し, $\alpha$ は安全係数で $\alpha=$ 1.5 とした ${ }^{11)}$.

同図より，すべての入力地震動において，降伏強 度が大きくなるにつれ，損傷度指標 DI の值が小さ くなっていることがわかる，その程度は入力地震動 によって異なっている．また，降伏強度に対する損 傷度指標の值も入力地震動によって異なり，この 3 波では，兵庫県南部地震 (神戸海洋気象台記録)，鳥 取県西部地震 (日野記録)，台湾集集地震 (TCU084 

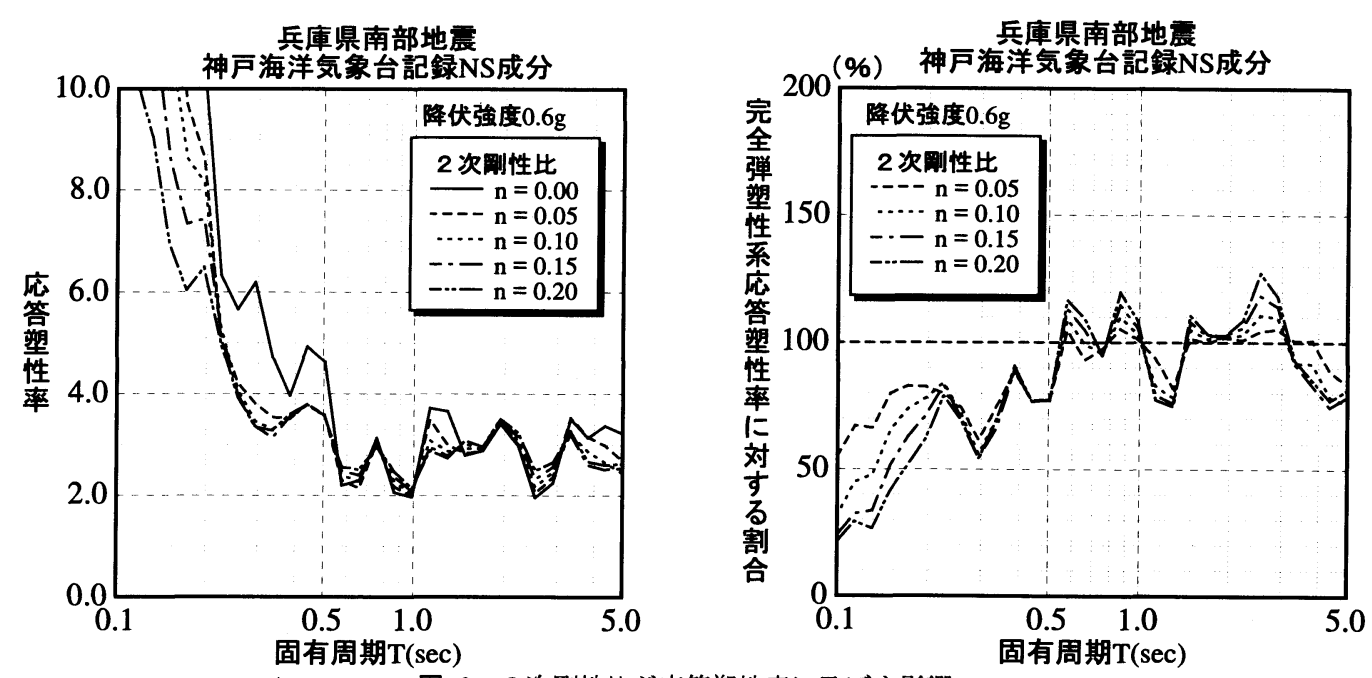

図-6２次剛性比が応答塑性率に及ぼす影響
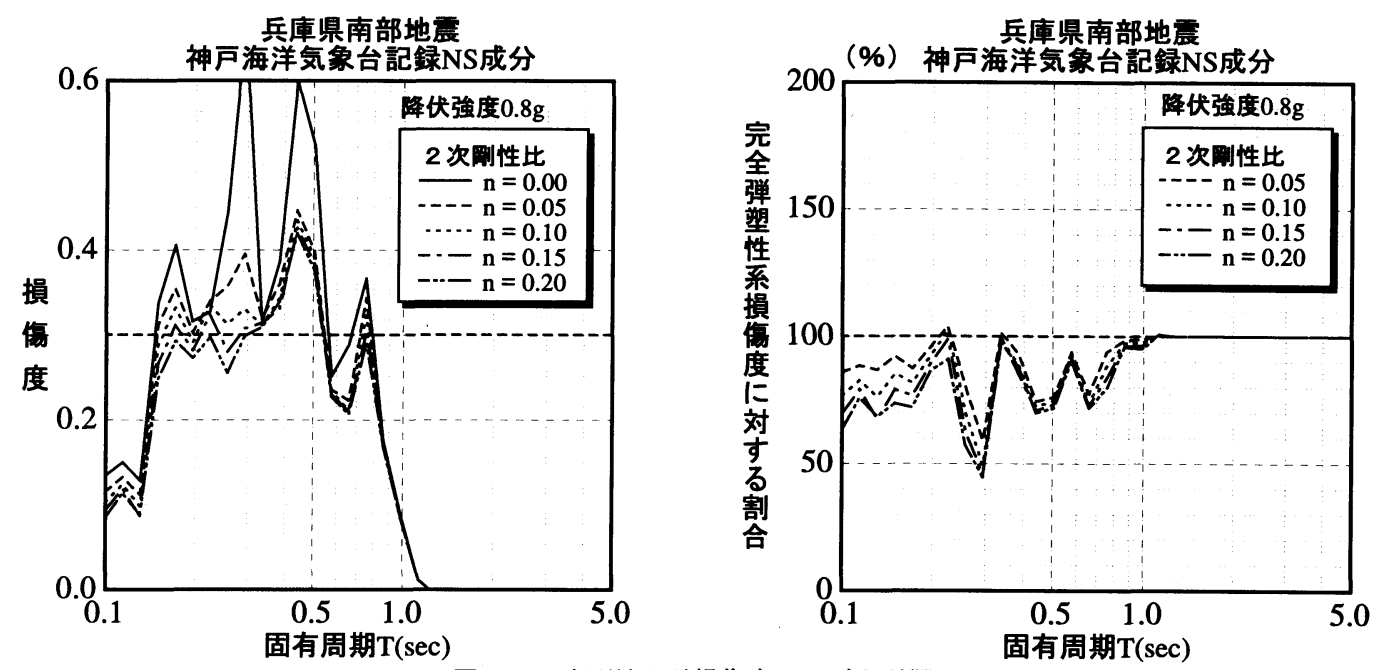

図-7 2 次剛性比が損傷度に及ぼす影響

EW）の順に，損傷が大きくなっている．現在の耐震 設計では, 強震下における構造物の損傷を表す指標 として, 応答塑性率 $\mu$ が用いられているが，使用し た損傷度指標は, 前述のように, 損傷の程度との対 応関係がつけやすいこと ${ }^{8)}$, 構造物の最大変形 (応 答塑性率) と履歴エネルギーの両方を取り入れいて いること ${ }^{20), 21)}$ などから，構造物の損傷を表すため のよりよい指標になり得ると考えられる．参考まで に, 表-1 によると, $D I>0.6$ が橋脚の崩壊を表すこ とから, 許容塑性率 $\mu a=5$, 寸なわち, 終局変位勒 性率 $\mu u=7$ の橋脚の崩壊を防ぐには, 弾性周期によ りその值は異なるが，概ね，兵庫県南部地震で $0.8 \mathrm{~g}$, 鳥取県西部地震で $0.9 \mathrm{~g}$, 台湾集集地震で $1.0 \mathrm{~g}$ 以上 の降伏強度を有する必要があると考えられる。

図-6は, 降伏強度 $P_{y}=0.6 \mathrm{~g}$, 入力地震動を兵庫県
南部地震・神戸海洋気象台記録NS成分とし, 2 次 剛性比 $n$ を $0.00 \sim 0.20$ に変化させた応答塑性率スペク トルである. また, 完全弾塑性系 $(n=0.00)$ の応答 塑性率に対する割合も示す. 図より，2次剛性比 $n$ の増加に伴い, 応答塑性率が小さくなっていること がわかる. その効果は, 2 次剛性比 $n=0.05$ とする だけで，かなりの効果があり，その傾向は $T<0.6 \mathrm{sec}$ で顕著になっている．完全弾塑性系に対する割合の 中で, 一部, 100\%を超えている部分が見られるが, これは，2 (3)a)に示したように，2次剛性比nが大 きくなることにより, 降伏変位が小さくなり, 応答 塑性率が大きくなっているのであり, 最大変位は大 きくなっていない.

図一7には, 降伏強度 $P_{y}=0.8 \mathrm{~g}$, 入力地震動を兵庫 県南部地震・神戸海洋気象台記録NS成分とし, 2 
表-2 耐震性能に対応する損傷度指標の限界值

\begin{tabular}{|c|c|c|}
\hline & \multicolumn{2}{|c|}{ 想定地震動 } \\
\cline { 2 - 3 } & L1地震動 & L2地震動 \\
\hline 耐震性能 I & 0.00 & \\
\hline 耐震性能 II & & 0.36 \\
\hline 耐震性能 III & & 0.60 \\
\hline
\end{tabular}

次剛性比 $n$ を $0.00 \sim 0.20$ に変化させた損傷度を示す. ここでの損傷度は，2（2）で述べた損傷度指標を用 いて算定した損傷度である，なお，式中の終局変位 勒性率は $\mu=7$, すなわち, 道路橋示方書における 許容塑性率 $\mu_{a}=5$ の構造物を想定したものとする. また，同図には，完全弾塑性系の損傷度に対する割 合も示す.これらの図より, 完全弾塑性系, 寸なわ ち, 2 次剛性比 $n=0.00$ では崩壊を表す $D I=0.6$ に達 するものが， 2 次剛性比 $n$ を大きくすると，修復可 能を表す $0.18<D I<0.36$ に損傷度が低減されている のがわかる. さらに, $T>1.0 \sec$ 弾性挙動を示して いる周期域以外の全ての周期域で， 2 次剛性比によ る損傷度 $D I$ の低減効果がみられる。

\section{3. 目標損傷度指標を満足する構造特性}

ここでは, 性能照査型設計で重要となる要求耐震 性能と 2 (2) の損傷度指標を対応させ, 目標耐震性 能に対応する損傷度指標の目標值を満たす弾性降伏 強度, 最大変位 (応答塑性率) という構造性能を導く ための 1 自由度系弾塑性応答解析の解析手法と解析 結果について説明する.

\section{（1）耐震性能と損傷度指標}

耐震に関わる要求性能は, 中小規模の地震動に対 しては補修が必要となるような損傷が発生しないこ と, および大規模地震動に対しては崩壊しないこと が基本になる (土木学会第二次提言)。これに対する 目標性能は, 想定地震動に応じて次の 3 段階に設定 することができる ${ }^{12)}$. (1)耐震性能 I：地震後にも補 修せずに機能を保持でき，かつ過大な変位を生じな い(L1 地震動). (2)耐震性能 II：地震後に補修を必 要とするが, 早期に機能が回復できる(L2地震動). (3)耐震性能而 : 地震によって構造物全体系が崩壊し ない(L2地震動).

表-1の関係と上述の要求耐震性能を対応させ, 図-1の「対応する構造限界の定義」として, それぞ
れの限界を, 耐震性能 I を弾性限界, 耐震性能 II を 修復可能限界, 而震性能而を崩壊しない限界と考え, 対応する損傷度指標DI の限界值と耐震性能の関係 を表-2のように設定した.ここで，耐震性能 I にお ける損傷度指標の目標值を $D I=0.00$ としたのは, 震 後の機能保持という観点から, 残留変位を生じては ならないと考え，あくまで完全弾性範囲内に構造物 の挙動を抑えるためである.

\section{（2）解析手法と入力地震動}

本研究ではBilinear型復元力特性を有する 1 自由 度系モデルに対する弾塑性エネルギー応答解析を 行った. その際, 減衰比 $h=0.05$, 終局変位勒性率 $\mu u=5$ とし, 固有周期 $T$ は $0.1 \sim 5.0$ 秒の範囲を対数軸 上に29等分した 30 通りの值を用いた. 時刻歴応答解 析終了後, 式(1)の損傷度指標DIを算定し, DI が目 標値と異なっている場合は, 降伏強度比 $R(\text { 式 }(8))^{10)}$ を変化させ，DI が目標值となるように解析を繰り 返すこととした.

$$
R=\frac{Q_{y}}{Q_{e \max }}
$$

ここで, $Q_{e} \max$ は最大弾性復元力, $Q y$ は降伏強度 を表す.

入力地震動は, 地盤条件を I 種地盤と想定し, L1 地震動として時刻歴応答解析用標準波形 I $(A \max =$ 102gal），L2地震動のType I 地震動として宮城県沖 地震 - 開北橋記録LG成分 $(A \max =319 \mathrm{gal})$, Type II 地震動として兵庫県南部地震 - 神戸海洋気象台記録 NS成分 $(A \max =812 \mathrm{gal})$ を用いた.

\section{（3）解析結果}

\section{a）必要降伏強度スペクトル}

図-8 は, 各耐震性能に対応寸る損傷度の限界值 を満たす降伏力のスペクトル，すなわち，必要降伏 強度スペクトルを示した図である. 左図は，L2 地 震動として開北橋記録 (Type I 地震動) を入力した結 果であり, 右図は, 神戸海洋気象台記録 (Type II 地 震動)を入力した結果である. 耐震性能 I は, 入力 地震動に L1 地震動 (標準波形 I ), 損傷度指標が $D I$ $=0.00$, 耐震性能 II は, 入力地震動に L2 地震動, 損傷度指標が $D I=0.36$, 耐震性能 $I I I$ は, 入力地震 動に L2 地震動, 損傷度指標が $D I=0.60$ として解析 した結果である. 同図より, 而震性能 I では, Type I 地震動, Type II 地震動ともに, $0.1 \mathrm{sec}<T<1.0 \mathrm{sec}$ で, $0.2 \mathrm{~g}$ を示している. 耐震性能 II では, Type I 地 

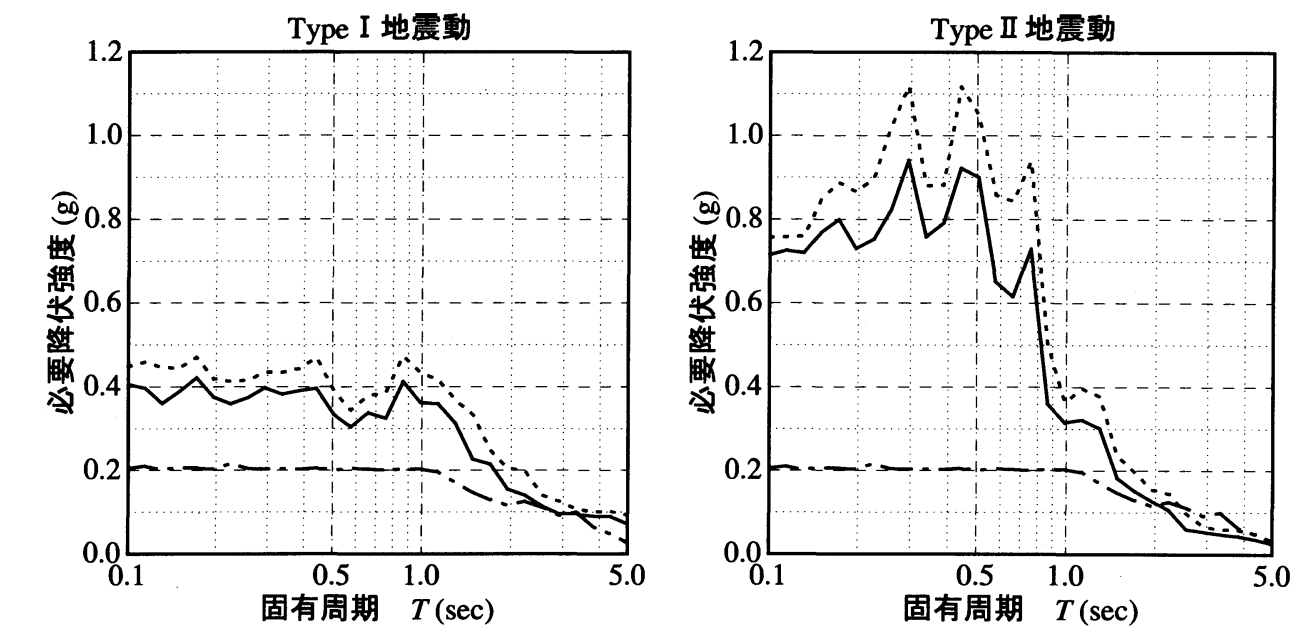

\section{‥-耐震性能 I （L1地震動），……耐震性能 II（L2地震動），一耐震性能III（L2地震動）}

図-8 損傷度指標の限界值を满たす必要降伏強度スペクトル（許容塑性率 $\mu a=3 ）$
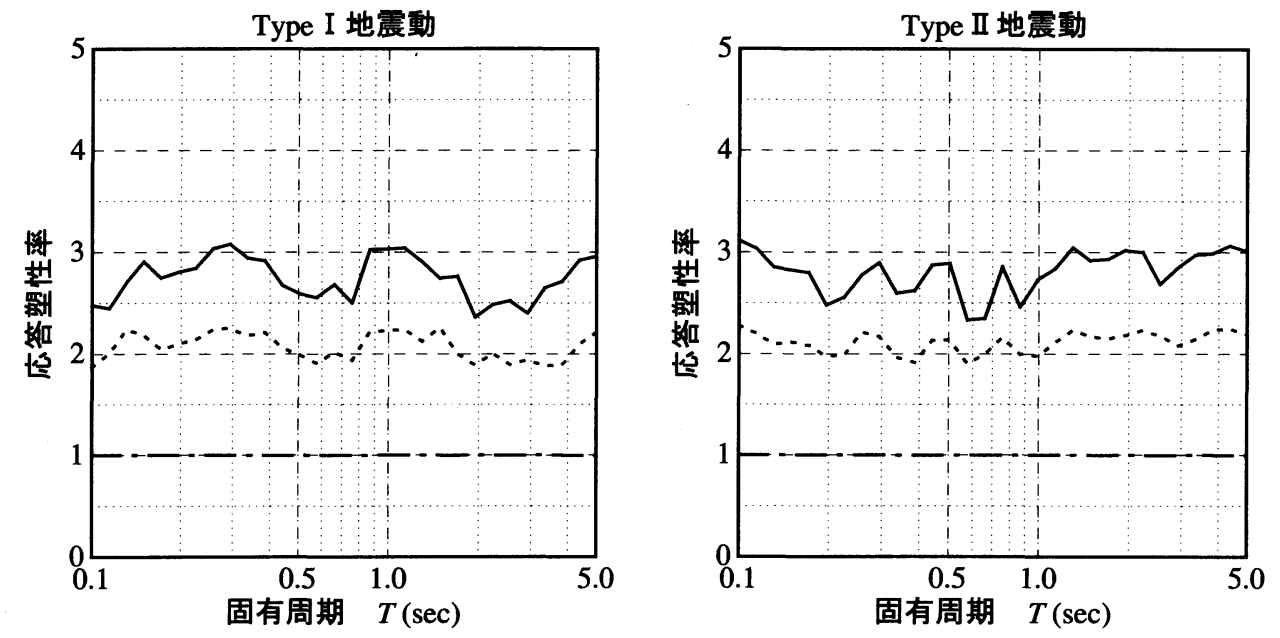

\section{‥一耐震性能 I（L1地震動），…西耐震性能 II（L2地震動），一耐震性能III（L2地震動）}

図-9＼cjkstart損傷度指標の限界值を満たす必要塑性率スペクトル（許容塑性率 $\mu_{a}=3 ）$

震動に関してはほぼ $0.45 \mathrm{~g}$ 程度, Type II 地震動に関 しては最大で $1.1 \mathrm{~g}$ 程度, 耐震性能III では, Type I 地震動に関してはほぼ $0.4 \mathrm{~g}$ 程度, Type II 地震動に 関しては最大で $0.9 \mathrm{~g}$ 程度となっている. Type II 地 震動に関してはかなり大きな值を示しているが, 弾 性周期によって值がばらついている上に, $T>1.0 \mathrm{sec}$ では, Type I 地震動とほぼ同じ値になっている．ま た，ほとんどの周期域で, 耐震性能が I , III， II の 順に, 必要降伏強度が大きくなっている.これは, 目標耐震性能から考えても妥当な結果と考えられる.

\section{b）必要塑性率スペクトル}

図-9には, 必要塑性率, すなわち, 最大応答変位 を降伏変位で除した值を示した．同図より，耐震性 能 I に対しては, 弾性限界であるので, 当然, 必要 塑性率は $\mu=1$ となっていることが確認できる. 耐 震性能 II ではほぼ $\mu=2$ 程度, 耐震性能ではほぼ $\mu$ $=3$ 程度となっており, 耐震性能の違いによる必要 塑性率がはっきり表れている. しかし, 耐震性能而 に対する必要塑性率 $\mu=3$ は, 道路橋示方書 ${ }^{11)}$ におい て, 本解析で想定した終局変位勒性率 $\mu_{u}=5$ を有す 

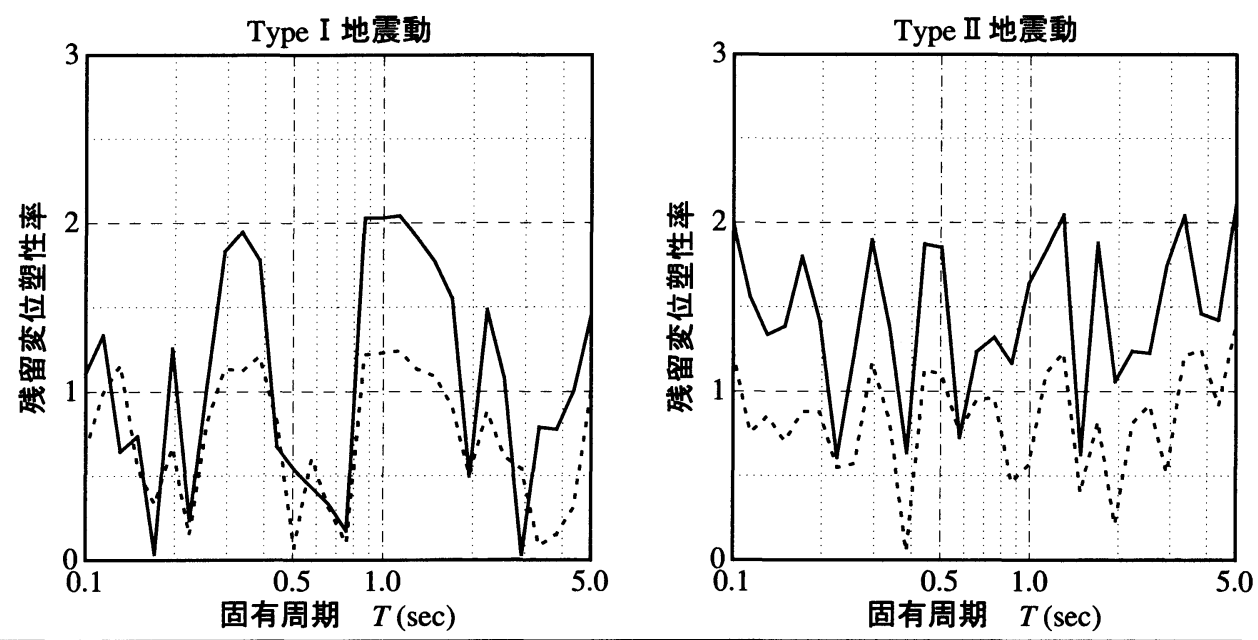

耐震性能 I（L1地震動），

- 耐震性能 II（L2地震動）。

耐震性能 III（L2地震動）

図-10 損傷度指標の限界值を満たす残留変位塑性率スペクトル（許容塑性率 $\mu_{a}=3 ）$

る鉄筋コンクリート橋脚の塑性変形性能に対し, 安 全係数 $\alpha$ を考慮して算定した許容塑性率 $\mu a$ と比較す ると, ほぼ等しい值になっている.一方で, 耐震性 能 II では，かなり小さ目の值になっている．これは 本研究で用いた損傷度指標の特色や設定した目標值 によって大きく変化する值であるので, 今後検討し ていく必要があると思われる.

ここで示した必要塑性率スペクトルは, a)の必要 弾性降伏強度スペクトルが, Type I 地震動とType II 地震動で大きく值が異なっているのに対して, 履 歴吸収エネルギーを考慮した損傷度指標を用いてい るにも関わらず, Type I 地震動と Type II 地震動で ほぼ同程度の值を示しており, 興味深い結果となっ ている.

\section{c）残留変位塑性率スペクトル}

図-10は, 各耐震性能に対応する残留変位塑性率 スペクトルを示したものである．耐震性能 I に対す る残留変位塑性率が生じていないが,これは耐震性 能 I が弾性限界であるためである，また，耐震性能 II では，地震後に補修を必要とするが，早期に機能 回復できるということから，この残留変位塑性率が 必要降伏強度および必要塑性率と合わせて, 目標性 能に用いる重要な限界値となると考えられる. 同図 より，ほとんどの周期域で, Type I 地震動および Type II 地震動ともに, 耐震性能 II では最大で残留変 位塑性率が1, 耐震性能 III では最大で2の值を示して いる.なお,これらの值は損傷度の目標値は満たし ている. 耐震性能III りも, 耐震性能 II の值が小さ くなっているのは, 前述したように, 耐震性能 II の
目標性能から考えても妥当な結果である. また, 弾 性周期により, 残留変位塑性率がかなり異なってい るが, これは入力地震動の卓越成分と弾性周期の関 係による影響と考え, 現行の道路橋示方書の動的解 析に関する規定にあるように, 入力地震動 3 波の平 均値を用いることによって, ある程度, 解消できる と思われるが, 今後, 損傷度指標と残留変位塑性率 の関係について, 検討の余地があると考えられる.

また, 本解析では, 復元力特性としてBilinear型の みを使用しているが，復元力特性が残留変位に及ぼ す影響は大きいと考えられている．この点について も, 他の復元力特性を用い, 比較・検討する必要が あると思われる.

以上の必要降伏強度スペクトル, 必要塑性率スペ クトルおよび残留変位塑性率スペクトルは, 異なっ た目標性能を満たす構造特性として算定することが でき, 損傷度指標を目標性能指標として用いること ができることが確認された. よって, 今後, 損傷度 指標と構造物の損傷状態, 要求性能と損傷度指標の 限界值の関係を吟味することにより，損傷度指標は 有用な目標性能指標になると思われる.

\section{4. おわりに}

本論文では，まず，地震時の構造物の損傷度に着 目した『性能評価を基盤にした設計体系の流れ』を 提案した. その中で用いる損傷度指標に対する入力 地震動や構造パラメータの影響について, 若干の解 
析を行い, その有用性の検討を行った. さらに, 構 造物の目標耐震性能に対応する損傷度指標の目標值 を設定し，1 自由度系弾塑性応答解析により，その 目標值を満たす降伏力や最大変位等の構造特性およ び残留変位を算定した。その結果から，性能照査型 設計法に用いる必要降伏強度 - 応答塑性率 - 残留変 位塑性率のスペクトルの作成を行なった. 得られた 知見を以下に示す.

1) 本論文で用いた損傷度指標は, 降伏強度が大き くなるにつれ, 小さくなり, その程度は, 入力 地震動により異なっている. また, 損傷度指標 と構造物の損傷の程度との対応関係が簡便であ ること, 構造物の最大変形と履歴エネルギーの 両方を取り入れていることから, 地震時の構造 物の損傷度ひいては性能を表すための, 合理的 な指標と考えられる。

2) 弾塑性復元力特性の 2 次剛性比 $n$ を大きくする と, 応答塑性率・損傷度指標が小さくなる. そ れらの効果は, 完全弾塑性系 $(n=0.0)$ と比較し て, $n=0.05$ とするだけでかなりの効果があり, その傾向は $T<0.6 \mathrm{sec}$ で顥著である. これは, 入 力地震動が兵庫県南部地震 - 神戸海洋気象台記 録 NS 成分であるため, 短周期域では履歴曲線 (応答変位波形) が塑性域に達してすぐに，十側

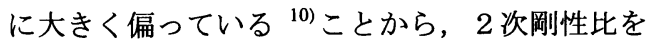
付加することにより履歴曲線が安定し, 最大変 位が低減されたからと考えられる，特に，損傷 度指標に対しては, 完全弾塑性系では崩壊に達 するものが, $n$ を大きくすることにより, 修復 可能なレベルに低減され，2次剛性比による耐 震性の向上が確認された.

3) 目標耐震性能を満足するのに必要な降伏強度ス ペクトルは, Type I 地震動と Type II 地震動では 異なった值を示しているが, 必要な塑性率スペ クトルは, Type I 地震動と Type II 地震動で, ほ ぼ同様の值を示している.このことは, 同一の 目標性能を満足するためには, Type II 地震動に 対して, 極めて高い降伏強度が必要であること を示している.

4) 残留変位スペクトルから, 機能回復可能な耐震 性能 II を満足するためには, 残留変位は $\delta$ y 以内, 崩壊を防ぐ耐震性能吕を満足するためには，2× 反y以内であることが必要であることが判った．

本論文で行なった解析的検討は, 限られた数值計 算により得られたものである，また，表-1，表-2に おける損傷度指標の值と損傷度の関係や, 式(1)に おける係数 $\beta$ の信賴性などが重要となってくる. 従って, 耐震性能と損傷度指標の関係, 減衰比等の
構造特性值による影響, 弾性周期に対する值のばら つき, 式(1)における係数 $\beta$ などについては, さら に, 検討していく必要があり, 今後の検討課題と考 えている，しかしながら，損傷度指標という地震時 の構造物の損傷度を定量的に表すことのできる指標 を用いることにより，目標性能指標を満足するため の必要降伏強度と塑性率のスペクトルの提案を行う ことができ, 損傷度指標が性能照査型設計法の目標 性能指標として有効であることが確認されたと考え られる。

\section{参考文献}

1) 家村浩和 : 極限地震力に対する要求性能と設計法のあ り方, 土木学会論文集, No.623/VI-43, pp.1-8, 1999.6.

2) Structural Engineers Association of California : Vision 2000 (Performance Based Seismic Engineering of Buildings), 1995.

3）市川篤司 : 鎆橋における性能を基盤にした設計体系へ の取り組み, 第 3 回鋼構造と橋に関するシンポジウム, 土木学会鋼構造委員会, 2000.8.30.

4) 伊藤義人, 織田博孝: 性能照查型の耐震設計法, 第 4 回土木鋼構造研究シンポジウム, 社団法人鋼材俱楽部, pp.20-25, 2000.1.14.

5) Park, Y.-J. and Ang, H.-S. : Mechanistic seismic damage model for reinforced concrete, Journal of Structural Engineering, Vo.111, No.4, pp.722-739, April 1985.

6) Krawinkler, H. and Zorei, M. : Cumulative damage in steel structures subjected to earthquake ground motion, Joumal of computers and structures, Vol.16, No.1-4, pp.531-541, 1983.

7) Kumar, S. and Usami, T. : A Note on the Evaluation of Damage in Steel Structures under Cyclic Loading, Jounal of Structural Engineering, Vol.40A, pp.177-188, March 1994.

8) 鈴木基行, 井林康, 藤原稔, 尾坂芳夫 : RC橋脚の地 震被害と地震動および構造特性との関連性, 構造工学 論文集, 土木学会, Vol.44A, pp.651-658, 1998.3.

9）井林康, 尾坂芳夫, 鈴木基行 : 地震入力エネルギーと 損傷指標を用いた RC橋脚の地震時損傷度評価に関す る研究, 構造工学論文集, 土木学会, Vol.46A, pp.807-814, 2000.3.

10) 三上卓, 家村浩和 : 性能照査型設計のための損傷度指 標, 第 4 回地震時保有耐力法に基づく橋梁の耐震設計 に関するシンポジウム講演論文集, 土木学会, pp.1724, 2000. 12.8 .

11) 日本道路協会 : 道路橋示方書 - 同解説, V 而震設計編, 丸善, pp.120-124, 1996.12. 
12) (財) 鉄道総合技術研究所 : 鉄道構造物等設計標準 - 同 解説 (耐震設計)，丸善，1999.

13) Ghobarah, A. and Aly, N.M. : Seismic reliability assessment of existing reinforced concrete buildings, Journal of Earthquake Engineering, Vol.2, No.4, pp.569$592,1998$.

14) Kunnath, S.K., Reinhorn, A.M. and Lobo, R.F. : A program for the inelastic damage analysis of reinforced concrete structures, Technical Report NCEER-92-0022, State University of New York at Buffalo, N.Y.

15) Singhal, A. and Kiremidjian, S. : Method for probabilistic evaluation of seismic structural damage, Journal of Structural Engineering, ASCE122, pp.1459-1467, 1996.

16) Ghobarah, A., Aly. N.M. and El-Attar, M. : Performance lebel criteria and evaluation, Seismic Design Methodologies for the Next Generation of Codes, Fajfar \& Krawinkler, Balkema, Rotterdam, ISBN, pp.207-215, 1997.

17) CDB Free-Field Strong-Motion Data from the 921 Chi-Chi Earthquake : Volume 1. Digital Acceleration Files on CDROM, Pre-Publication Version (December 6, 1999),
Seismology Center, Central Weather Bureau, Taipei, Taiwan.

18) 防災科学技術研究所：基盤強震観測網（KiK-net） http://www.kik.bosai.go.jp/kik/

19) 家村浩和, 高橋良和, 曽我部直樹, 樢飼正裕 : アンボ ンド高強度芯材を用いたRC橋脚の高耐震化に関する 基礎的研究, 第 4 回地震時保有耐力法に基づく橋梁の 耐震設計に関するシンポジウム講演論文集, 土木学会 pp.433-438, 2000. 12.8 .

20) 平尾潔, 笹田修司, 成行義文, 澤田勉, 川端茂樹 : 所 要降伏強度比スペクトルとこれを用いた強震時終局安 全性の一照査方法について, 土木学会論文集, No.525 /I-33, pp.213-225, 1995.10.

21) 成行義文 : 強震下における構造物のエネルギ一応答の 推定と損傷度評価に関する基礎的研究, 京都大学博士 論文, 1992.4 .

\section{DEMAND SPECTRA OF YIELDING STRENGTH AND DUCTILITY FACTOR FOR REQUIRED SEISMIC PERFORMANCE OBJECTIVES}

\section{Hirokazu IEMURA and Taku MIKAMI}

Performanse based design concept has recently been adopted as the design criteria of various structures. To realize the concept, relation between level of structure damage and performance objectives has to be quantitatively discussed. In this paper, the damage index of inelastic structures is employed as a measure of seismic performance objectives. With numerical simulation of inelastic seismic response, demand spectra of yielding strength and ductility factor to satisfy the required seismic performance are presented. It is found that much higher yield strength is needed for nearfield earthquake motion compared to far field earthquake motion for the same level of performance objectives. 